\title{
Assessment of Food Safety and Sanitation Standards of Canteens in Nueva Ecija
}

\author{
Ma. Cecilia P. Reyes
}

Nueva Ecija University of Science and Technology, Philippines

\begin{abstract}
Food safety is a particularly worrying environmental health problem in universities. This study used descriptive method of research. A total of 172 respondents from different universities were surveyed.Findings in this study reported that adherence to school canteen rules and government regulations play important roles in influencing food handlers' attitude towards safe food handling. It was found that perceived barrier generally do not hinder safe food handling. However, small working space, inconvenient location for kitchen equipment and unavailability of food handling guideline toward achieving safe food handling were individual items in the questionnaire that scored high.
\end{abstract}

Keywords-School Canteens, Canteens, Food Safety, Food Sanitation, Safety Standard, Sanitation Standard.

\section{INTRODUCTION}

Food safety is a particularly worrying environmental health problem in universities. Sharif et al. (2013) stated that improper food handling activity and lack of knowledge are contributing factors for the transmission of food borne outbreaks.

Furthermore, Yan (2012) explained that the magnitude of the potential danger has yet to be adequately understood, as demonstrated by the lack of a detailed account of the broader implications of food safety concerns and expectations of food risk.

Osimani et al. (2014) concluded that the implementation of punitive steps against bad hygiene, such as re-cleaning undesirable surfaces or replacing/regenerating damaged work surfaces.

Nee and Sani (2011) reported that the level of expertise of food handlers in this sample can be rated as fair with an average score of $57.8 \%$. Thus, Zain and Naing (2002) recommended that Training, preparation, and the production of food safety certification exams are key components in ensuring that food handlers are qualified in and educated about the values of food safety and sanitation.

In light of the foregoing insights, the researcher's piqued its interest in the assessment of the food standards, in terms of safety and sanitation, if it was being complied by the food handles among the universities in Nueva Ecija.

\section{CONCEPTUAL FRAMEWORK}

According to Ababio and Adi (2012), the realistic dimension was not fully understood by the food handlers and they did not have any technical understanding of the procedures that could be performed to guarantee food safety.

Lee et al. (2017) reported that food handlers had a reasonable level of knowledge of food safety with a good attitude, and self-reported habits, the poor performance in hand hygiene appraisal showed an inability to regularly practice safe handling of food in their job.

Evidenced in the study of Meleko (2013), Poor accessibility and cleanliness of latrine service in some canteens and food handlers ' general hygiene routine portrays that most of them had poor practice of food handling.

\section{OBJECTIVE OF THE STUDY}

This paper described the food handlers and operations of canteen in their compliance to food safety standards andfood sanitation standards.

\section{METHODOLOGY}

The study used descriptive method as it describes the present condition. As the main objective of this method is to describe practices that prevail; and beliefs and processes that are going on; effects that being felt or trends that are developing. (Cohen et al., 2002)

A total of 172 respondents from different universities were surveyed. The researcher used likert-scale type questionnaire 
(Vagias, 2006) and analyzed it through statistical data treatment such as mean and weighted mean.

\section{RESULTS AND DISCUSSION}

Table 1. Food Safety Standards

\begin{tabular}{|l|c|c|}
\hline \multicolumn{1}{|c|}{ Standards } & WM & $\begin{array}{c}\text { Verbal } \\
\text { Interpretation }\end{array}$ \\
\hline Tied hair while preparing foods. & 3.28 & Always \\
\hline $\begin{array}{l}\text { Wearing clean protective } \\
\text { clothing. }\end{array}$ & 0.54 & Never \\
\hline $\begin{array}{l}\text { Washing hands thoroughly with } \\
\text { warm soapy water. }\end{array}$ & 3.60 & Always \\
\hline $\begin{array}{l}\text { Cold foods are kept } 5^{\circ} \mathrm{C} \text { or } \\
\text { below. }\end{array}$ & 3.88 & Always \\
\hline $\begin{array}{l}\text { Hot foods are kept } 60^{\circ} \mathrm{C} \text { or } \\
\text { below. }\end{array}$ & 3.68 & Always \\
\hline Foods are $60^{\circ} \mathrm{C}$ or above & 3.48 & Always \\
\hline $\begin{array}{l}\text { Covering or removing jewelry } \\
\text { that may contaminate food. }\end{array}$ & 3.68 & Always \\
\hline $\begin{array}{l}\text { Ready to eat foods are covered } \\
\text { and stored above veg. And meat } \\
\text { in a fridge. }\end{array}$ & 3.52 & Always \\
\hline $\begin{array}{l}\text { Raw meat are kept in sealed } \\
\text { containers in the bottom or the } \\
\text { fridge. }\end{array}$ & 3.52 & Always \\
\hline $\begin{array}{l}\text { Use tongs, spoons, bags, or paper } \\
\text { to serve unpacked foods. }\end{array}$ & 3.52 & Always \\
\hline \multicolumn{1}{|c|}{ Average Weighted Mean } & $\mathbf{3 . 2 7}$ & Always \\
\hline
\end{tabular}

Table 1 presents the food practices of the respondents according to food safety standards. The statement "Cold foods are kept $5{ }^{\circ} \mathrm{C}$ or below" hadthe highest weighted mean of "3.88" with an interpretation of "Always". On the other hand, the statement "Wearing clean protective clothing" had the lowest weighted mean of " 0.54 " and an interpretation, "Never."

Table 2. Food Sanitation Standards

\begin{tabular}{|c|c|c|}
\hline Standards & WM & $\begin{array}{c}\text { Verbal } \\
\text { interpretation }\end{array}$ \\
\hline $\begin{array}{c}\text { Tables and chairs are clean } \\
\text { permanently installed. }\end{array}$ & 3.44 & Always \\
\hline $\begin{array}{c}\text { Having good personal hygiene } \\
\text { (shorts fingernails without painting) } \\
\text { during handling food. }\end{array}$ & 3.64 & Always \\
\hline $\begin{array}{c}\text { Cooked foods are displayed in } \\
\text { cabinet that can facilitate consumer }\end{array}$ & 3.56 & Always \\
\hline
\end{tabular}

\begin{tabular}{|c|c|c|}
\hline to see the food. & & \\
\hline $\begin{array}{c}\text { Using ladle or spoon with a long } \\
\text { handling for serving. }\end{array}$ & 3.60 & Always \\
\hline $\begin{array}{c}\text { Cooking and eating utensils are } \\
\text { sterilized. }\end{array}$ & 3.60 & Always \\
\hline $\begin{array}{c}\text { Changing chopping board and } \\
\text { utensilseverytime you prepare new } \\
\text { type of food. }\end{array}$ & 3.52 & Always \\
\hline Non- smoking while preparing foods. & 3.68 & Always \\
\hline Foods are free from pest and vermin. & 3.52 & Always \\
\hline Disposing of garbage regularly. & 3.68 & Always \\
\hline Average Weighted Mean & $\mathbf{3 . 5 7}$ & Always \\
\hline
\end{tabular}

Table 2 presents the practices of respondents according to food sanitation standards. The statement "Changing chopping board and utensils every time you prepare new type of food", "Non- smoking while preparing food", and "Disposing of garbage regularly" had the highest weighted mean of "3.68\%" and wereinterpreted as "Always". On contrary, gaining the lowest weighted mean of " $3.44 \%$ " with an interpretation of "Always" was the statement, "Tables and chairs are clean permanently installed."

\section{CONCLUSION}

Findings in this study reported that adherence to school canteen rules and government regulations play important roles in influencing food handlers' attitude towards safe food handling. It was found that perceived barrier generally do not hinder safe food handling. However, small working space, inconvenient location for kitchen equipment and unavailability of food handling guideline toward achieving safe food handling were individual items in the questionnaire that scored high. In addition, not only school canteens food handlers but also all of the food handlers should be given more awareness on food safety and hygiene practices and personal hygiene to prevent outbreak and spread of foodborne diseases to customers especially for students and teachers.

\section{REFERENCES}

[1] Ababio, P. F., \&Adi, D. D. (2012). Evaluating food hygiene awareness and practices of food handlers in the Kumasi metropolis. Internet Journal of Food Safety, 14(2), 35-43.

[2] Cohen, L., Manion, L., \& Morrison, K. (2002). Research methods in education. routledge.

[3] Lee, H., Abdul Halim, H., Thong, K., \& Chai, L. (2017). Assessment of food safety knowledge, attitude, self-reported practices, and microbiological hand hygiene of food 
handlers. International Journal of Environmental Research and Public Health, 14(1), 55.

[4] Meleko, A. (2013). Assessment of the sanitary conditions of catering establishments and food safety knowledge and practices of food handlers in Addis Ababa University Students' Cafeteria (Doctoral dissertation, Addis AbebaUniversty).

[5] Nee, S. O., \& Sani, N. A. (2011). Assessment of knowledge, attitudes and practices (KAP) among food handlers at residential colleges and canteen regarding food safety. SainsMalaysiana, 40(4), 403-410.

[6] Osimani, A., Garofalo, C., Clementi, F., Tavoletti, S., \&Aquilanti, L. (2014). Bioluminescence ATP monitoring for the routine assessment of food contact surface cleanliness in a university canteen. International journal of environmental research and public health, 11(10), 10824-10837.

[7] Sharif, L., Obaidat, M. M., \& Al-Dalalah, M. R. (2013). Food hygiene knowledge, attitudes and practices of the food handlers in the military hospitals. Food and Nutrition Sciences, 4(03), 245.

[8] Vagias, W. M. (2006). Likert-type scale response anchors. clemson international institute for tourism. \& Research Development, Department of Parks, Recreation and Tourism Management, Clemson University

[9] Yan, Y. (2012). Food safety and social risk in contemporary China. The Journal of Asian Studies, 71(3), 705-729.

[10] Zain, M. M., \&Naing, N. N. (2002). Sociodemographic characteristics of food handlers and their knowledge, attitude and practice towards food sanitation: a preliminary report. Southeast Asian journal of tropical medicine and public health, 33(2), 410-417. 